\title{
STRATEGI PENGEMBANGAN AGRIBISNIS TERNAK SAPI DI KABUPATEN SUMBAWA BARAT
}

\author{
Muhammad Nursan ${ }^{1)^{*}}$, Sukarne ${ }^{2)}$ \\ 1)*Dosen Program Studi Agribisnis, Fakultas Pertanian Universitas Mataram \\ ${ }^{2)}$ Dosen Program Studi Ilmu Peternakan, Fakultas Peternakan Universitas Mataram \\ Email: mnursan@yahoo.co.id ${ }^{1{ }^{*}}$, sukarne1990@ gmail.com ${ }^{2)}$
}

\begin{abstract}
ABSTRAK
Kabupaten Sumbawa Barat merupakan salah satu wilayah potensial pengembangan agribisnis ternak sapi di Indonesia karena didukung dengan ketersediaan sumberdaya lahan dan adanya taman teknologi pertanian sebagai pusat pengembangan agribisnis ternak sapi dan jagung. Keberhasilan pengembangan agribinsi ternak sapi ini sangat tergantung pada pemilihan dan penerapan strategi yang sesuai dengan karakteristik wilayah. Tujuan penelitian ini dilakukan yaitu untuk menentukan wilayah basis pengembangan dan merumuskan strategi pengembangan agribisnis ternak sapi di Kabupaten Sumbawa Barat. Metode penelitian yang digunakan pada penelitian ini adalah metode deskriptif. Data pada penelitian ini terdiri atas data primer dan data skunder. Data primer bersumber dari hasil wawancara terhadap 40 responden yang dipilih secara purposive sampling sedangkan data skunder bersumber dari Dinas terkait seperti BPS Kabupaten Sumbawa Barat, Dinas Pertanian, perkebunan dan peternakan Kabupaten Sumbawa Barat dan lainnya. Data yang berhasil dikumpulkan dianalisis menggunakan analisis LQ dan Analisis SWOT. Hasil penelitian menunjukkan bahwa wilayah pengembangan agribisnis ternak sapi di Kabupaten Sumbawa Barat dapat dilakukan di 6 kecamatan yang meliputi Kecamatan Sekongkang, Maluk, Jereweh, Seteluk dan Poto Tano. Strategi pengembangan agribisnis yang perlu diterapkan yaitu strategi strength-opportunity (SO) yang meliputi strategi Peningkatan populasi dan produktivitas ternak sapi dengan memanfaatkan teknologi reproduksi, dan taman teknologi pertanian, meningkatkan pengetahuan dan keterampilan SDM peternak melalui pelatihan manajemn usaha dan pemanfaatan teknologi peternakan, integrasi sistem agribisnis ternak sapi dari hulu ke hilir, optimalisasi peran dan dukungan pemerintah dan swasta dalam mengembangkan usaha agribisnis ternak sapi.
\end{abstract}

Kata kunci: Strategi Pengembangan, Agribisnis, Ternak Sapi, Analisis LQ, Analisis SWOT

\section{PENDAHULUAN}

Salah satu subsektor pertanian yang penting untuk dikembangkan adalah subsektor peternakan. Hal ini dikarenakan subsektor ini merupakan salah satu penghasil pangan, daging dan juga banyak masyarakat yang menjadikannya sebagai salah satu mata pencarian utama (Nursan \& Septiadi, 2020). Dengan ada peran penting tersebut maka pembangunan peternakan harus diarahkan untuk peningkatan produksi ternak dan pendapatan peternak.

Komoditas peternakan sapi merupakan penghasil daging terbesar dalam pemenuhan pangan sumber protein hewani dan sudah dimasukkan ke dalam salah satu komoditas strategis dalam perencanaan 
pembangunan subsektor peternakan oleh pemerintah pusat (Ditjen PKH, 2011).

Saat ini konsumsi daging sapi nasional selalu menunjukkan peningkatan dari ke tahun, begitu juga dengan impor daging maupun bakalan sapi juga terus bertambah. Kondisi ini menandakan bahwa perlu adanya strategi dalam rangka pengembangan peternakan sapi secara nasional agar impor bisa dikurangi (Priyanto, 2011).

Konsumsi daging sapi yang tinggi belum dapat dipenuhi oleh produksi dalam negeri karena tingkat populasi dan produktivitas ternak sapi yang masih rendah (Hilmiati, 2019). Kemudian penyebab rendahnya populasi dan produktivitas ternak sapi ini disebabkan kurangnya pengetahuan masyarakat mengenai manajemen pembibitan, teknologi atau ketersediaan pakan berkelanjutan (Yulianti et al., 2021). Lebih khusus lagi di pulau Sumbawa jumlah populasi sapi tidak diimbangi dengan kualitas ternak sapi itu sendiri. Rendahnya kualitas sapi tersebut dipengaruhi oleh inbreeding (Otoluwa et al., 2016), perkawinan alam yang tidak teratur akibat sistem pemeliharaan lar yang tidak terkontrol.

Kesenjangan antara produksi dan konsumsi daging sapi ini menunjukkan bahwa peternakan sapi nasional masih lemah dan belum kompetitif. Dimana masih tingginya import sapi potong, daging sapi dan produk derivasi lainya merupakan respon dari tingginya permintaan domestik. Banyak faktor-faktor yang dapat menjadi penghambat pengembangan peternakan sapi nasional, tetapi secara umum disebabkan oleh kurangnya manajerial dan belum mengembangkan sistem agribisnis sapi yang memenuhi standar pasar (Khusna et al., 2016).
Kabupaten Sumbawa Barat merupakan salah satu kabupaten penghasil sapi di Provinsi Nusa Tenggara Barat (NTB) dengan jumlah populasi sapi sebesar 80933 ekor (BPS KSB, 2021). Kabupaten ini memiliki zonasi strategis terhadap aktivitas bisnis antar pulau di Propinsi NTB serta menjadi pasar bisnis dari wilayah timur Pulau Sumbawa dengan akses maupun pertumbuhan ekonomi bisnis yang cukup berpeluang pada sektor peternakan terutama kemampuan untuk memenuhi kebutuhan daging bagi daerah-daerah lain baik di NTB maupun daerah di luar NTB. Selain itu, kabupaten ini menjadi penempatan pusat Regional Manajemen Pulau Sumbawa (RMPS) yang memiliki peran penting dan strategis untuk menentukan pemetaan wilayah maupun tata kelola pengembangan agribisnis sapi di masa-masa yang akan datang. Salah satu alternatif pengembangan peternakan sapi untuk dapat memenuhi permintaan daging sapi baik secara nasional maupun regional di KSB adalah melalui pengembangan agribisnis (Suryana, 2009). Dimana Pengembangan agribisnis Sapi di Indonesia memiliki prospek sangat besar karena tingginya permintaan pasar baik produk daging sapi, susu maupun kulit (Siregar, 2012). Selain itu, adanya penduduk indonesia yang sebesar 200 juta lebih jiwa, globalisasi perdagangan seperti APEC, AFTA, dan WTO, dan berkembnganya idustri-indutrsi pengolahan hasil ternak menjadi peluang besar agribisnis peternakan perlu dikembangkan (Mukson et al., 2014). Pengembangan agribisnis sapi dapat dicapai dengan baik dengan terlebih dahulu melakukan pemetaan wilayah berbasis komoditas unggulan yang merupakan faktor pendukung dalam meningkatkan keberhasilan pembangunan daerah, peningkatan pendapatan dan kesejahteraan 
masyarakat (Kurniawan, 2016). Rustiadi et al., (2011) mengatakan bahwa wilayah basis merupakan sistem pengelompokkan komoditas berdasarkan wilayah yang berguna memberikan efisiensi dalam hal produksi dan pendistribusian suatu komoditas serta dapat dijadikan upaya peningkatan keunggulan komparatif wilayah.

Selain itu juga pengembangan agribisnis ternak sapi juga perlu dilakukan pengelompokkan wilayah yang daya dukung lahan dan pakan hijauannya sesuai (Mayulu et al., (2010); Arelovich et al., (2011); Priyanto, (2011); Huyen et al., (2012). Oleh karena itu tujuan penelitian ini adalah menentukan wilayah basis pengembangan dan merumuskan strategi pengembangan agribisnis ternak sapi di Kabupaten Sumbawa Barat.

\section{METODE PENELITIAN}

Penelitian ini di laksanakan di Kabupaten Sumbawa Barat yang dipilih secara purposive sampling waktu penelitian dilakukan pada bulan Oktober- Desember tahun 2017. Penelitian ini termasuk kedalam penelitian deskriptif kuantitatif. Data yang digunakan pada penelitian ini meliputi data sekunder dan Cross section. Pengumpulan data Cross section dilakukan dengan teknik survei (Sugiyono, 2014), menggunakan kuesioner penelitian terhadap 40 responden yang dipilih secara purposive sampling. Setelah data diperoleh kemudian dianalisis berdasarkan tujuan penelitian yaitu untuk menentukan wilayah basis pengembangan ternak sapi digunakan metode analisis LQ (Location Quotient). Adapun rumus metode LQ yaitu sebagai berikut Tarigan, (2014), Susanti et al., (2014), dan Nursan, (2017):
$\mathrm{LQ}=(x i c / x t c) /(X i k / X t k)$

Dimana:

xic : Total populasi ternak $\mathrm{i}$ di tingkat kecamatan

xc : Total populasi semua jenis ternak $t \mathrm{di}$ tingkat kecamatan

Xik : Total populasi ternak i di tingkat kabupaten

Xtk : Total populasi semua jenis ternak $t$ di wilayah kabupaten

Keterangan nilai LQ:

LQ > 1 : artinya komoditas ternak tersebut merupakan basis pada wilayah tersebut.

LQ = $1:$ komoditas ternak tersebut belum termasuk basis pada wilayah tersebut.

LQ < 1 : komoditas ternak tersebut tidak tergolong basis pada wilayah tersebut.

Kemudian untuk merumuskan strategi pengembangan agribisnis ternak sapi digunakan analisis SWOT (strength, weakness, opportunity, threats) yaitu melakukan identifikasi dan analisis secara sistematis mengenai faktor internal yaitu kekuatan (strength) dan kelemahan (weakness) dan eksternal berupa peluang (opportunity) dan ancaman (threats) dalam merumuskan strategi (Rangkuti, 2015).

\section{HASIL DAN PEMBAHASAN \\ Penentuan Wilayah Basis Pengembangan Agribisnis Sapi}

Penentuan wilayah basis pengembangan agribisnis sapi pada penelitian ini dilakukan dengan menggunakan metode analisis LQ. Analisis ini dapat menjelasakan bahawa komoditas tertentu merupakan basis pada suatu wilayah tertentu. Dimana jika Nilai LQ > 1, berarti komoditas merupakan basis pada suatu wilayah, nilai $L Q=1$, berarti komoditas belum tergolong basis pada suatu wilayah; dan nilai LQ $<1$, berarti komoditas tersebut tidak termasuk basis pada suatu wilayah tertentu (Tarigan, 2014). Adapun hasil analisis penentuan wilayah basis 
pengembangan agribisnis sapi di Kabupaten

berikut ini.

Sumbawa Barat disajikan pada tabel 1

Tabel 1. Hasil Analisis LQ Jenis Ternak Ruminansia di Kabupaten Sumbawa Barat Tahun 2017

\begin{tabular}{|l|l|l|l|l|l|}
\hline Kecamatan & Sapi & Kerbau & Kambing & Domba & Kuda \\
\hline Sekongkang & 1.0313 & 0.9018 & 0.8724 & 0.5688 & 0.9167 \\
\hline Jereweh & 1.0354 & 0.7756 & 1.4349 & 2.8280 & 0.6985 \\
\hline Maluk & 1.0650 & 0.8024 & 0.3219 & - & 1.0625 \\
\hline Taliwang & 1.0004 & 1.0164 & 0.5023 & 1.1331 & 1.2535 \\
\hline Brang Ene & 0.9902 & 1.0776 & 0.9069 & - & 1.0548 \\
\hline Brang Rea & 0.7457 & 2.0694 & 0.2944 & 0.4775 & 2.3326 \\
\hline Seteluk & 1.0073 & 1.0554 & 1.0836 & - & 0.8024 \\
\hline Poto Tano & 1.0795 & 0.5642 & 1.6789 & 1.4485 & 0.4868 \\
\hline
\end{tabular}

Sumber: Data Primer Diolah (2017)

Berdasarkan hasil analisis LQ pada tabel 1 menunjukkan bahwa wilayah basis pengembangan untuk ternak sapi terdapat pada 6 kecamatan yang meliputi Kecamatan Sekongkang, Maluk, Jereweh, Taliwang, Seteluk dan Poto Tano. Hasil ini sesuai juga dengan temuan Nursan \& Septiadi (2020) yang mengatakan bahwa wilayah basis pengembangan ternak sapi meliputi Kecamatan Jereweh, Maluk, Taliwang dan Seteluk. Selain itu, kecamatan-kecamatan tersebut juga memiliki daya dukung lahan dan pakan hijauan yang cukup memadai dalam mendukung pengembangan agribisnis ternak sapi di Kabupaten Sumbawa Barat. Dimana menurut Nursan (2017) menyatakan bahwa kecamatan tersebut merupakan wilayah basis pengembangan beberapa komoditas tanaman pangan yang merupakan sumber pakan untuk ternak sapi.

\section{Analisis SWOT Agribisnis Sapi}

Perumusan strategi pengembangan agribisnis sapi disusun berdasarkan hasil analisis SWOT. Dimana dalam analisis SWOT dilakukan kajian mendalam tentang faktor internal (kekuatan dan kelemahan) dan faktor eksternal (peluang dan ancaman) untuk mendapat suatu strategi (Rangkuti, 2015). Analisis SWOT ini sangat tepat digunakan untuk merumuskan strategi pengembangan agribisnis sapi di Kabupaten Sumbawa Barat, dan telah banyak digunakan oleh peneliti sebelumnya dalam merumuskan stategi pengembangan seperti pada penelitian Khusna et al., (2016), Ariani \& Nursan (2017), Putritamara et al., (2018). Dalam kajian ini, faktor internal dan eksternal tersebut diperinci lagi menjadi factor kekuatan, peluang, kelemahan dan ancaman.

a) Faktor Internal

Faktor internal terdiri atas faktor kekuatan (strength) dan faktor kelemahan (weakness). Faktor kekuatan pengembangan agribisnis ternak sapi di Kabupaten Sumbawa Barat meliputi:

1. Populasi ternak sapi tinggi

2. Ketersediaan SDM peternak tinggi

3. Dukungan pemerintah dan swasta

4. Adanya teknologi reproduksi

5. Adanya kelembagaan peternakan Kemudian masih ditemukan beberapa faktor kelemahan pengembangan agribisnis ternak sapi di Kabupaten Sumbawa Barat seperti:

1. Sistem perkandangan yang belum terintegrasi

2. Kualitas SDM peternak masih rendah 
3. Jumlah petugas peternakan masih kurang

4. Kurangnya ketersediaan dan pengelolaan pemanfaatan saranaprasarana agribisnis ternak
5. Sistem peternakan yang masih tradisional

Tabel 2. Hasil Analisis Faktor Internal

\begin{tabular}{|c|c|c|c|}
\hline Faktor-faktor strategis & Bobot & Rating & Skor \\
\hline \multicolumn{4}{|l|}{ Kekuatan } \\
\hline Populasi ternak sapi tinggi & 0.091 & 4 & 0.364 \\
\hline Jumlah SDM peternak sapi tinggi & 0.121 & 4 & 0.485 \\
\hline Dukungan pemerintah dan swasta & 0.121 & 3 & 0.364 \\
\hline Adanya teknologi reproduksi & 0.091 & 3 & 0.273 \\
\hline \multirow[t]{2}{*}{ Adanya kelembagaan peternakan } & 0.091 & 2 & 0.182 \\
\hline & 0.515 & & 1.667 \\
\hline \multicolumn{4}{|l|}{ Kelemahan } \\
\hline Sistem perkandangan yang belum terintegrasi & 0.091 & 3 & 0.273 \\
\hline Kualitas SDM peternak & 0.121 & 3 & 0.364 \\
\hline Jumlah petugas peternakan masih kurang & 0.091 & 2 & 0.182 \\
\hline $\begin{array}{l}\text { Kurangnya ketersediaan dan pengelolaan sarana- } \\
\text { prasarana agribisnis ternak }\end{array}$ & 0.121 & 2 & 0.242 \\
\hline \multirow[t]{2}{*}{ Sistem peternakan yang masih tradisional } & 0.061 & 3 & 0.182 \\
\hline & 0.485 & & 1.242 \\
\hline Total & 1.000 & & 0.424 \\
\hline
\end{tabular}

Hasil analisis faktor internal yang terdiri atas faktor kekuatan (streght) dan kelemahan (weakness) menunjukkan bahwa faktor kekuatan lebih dominan dibandingkan dengan faktor kelemahan dengan nilai selisih sebesar 0.424. Faktor kekuatan berdasarkan hasil analisis faktor internal memiliki nilai sebesar 1.667 sedangkan faktor internal memiliki nilai sebesar 1.242. Dalam rangka pengembangan agribisnis ternak sapi di Kabupaten Sumbawa Barat maka perlu mengoptimalkan kekuatan yang dimiliki dalam mengatasi kelemahan.

b) Faktor Eksternal

Faktor ekternal terdiri atas faktor peluang (opportunity) dan ancaman (threats). Adapun peluang yang perlu dimanfaatkan untuk pengembangan agribisnis sapi di Kabupaten Sumbawa Barat meliputi:

1. Permintaan ternak sapi baik dari dalam maupun luar daerah tinggi

2. Industri pengolahan

3. Adanya Taman Teknologi Pertanian (integrasi sapi-jagung)

4. Pengembangan usaha/ pemasaran

5. Harga jual sapi tinggi

Selain adanya peluang, ada beberapa ancaman atau tantangan pengembangan agribisnis sapi di Kabupaten Sumbawa Barat seperti:

1. Penyakit dari luar daerah

2. Keamanan ternak sapi

3. Perubahan iklim dan cuaca

4. Adanya pesaing dari luar 
Tabel 3. Hasil Analisis Faktor Eksternal

\begin{tabular}{lccc}
\hline Faktor-faktor strategis & Bobot & Rangking & Skor \\
\hline Peluang & & & \\
Permintaan ternak sapi baik dari dalam maupun luar daerah & & & \\
tinggi & 0.143 & 4 & 0.571 \\
Industri pengolahan & 0.107 & 3 & 0.321 \\
Adanya Taman Teknologi Pertanian (integrasi sapi-jagung) & 0.143 & 2 & 0.286 \\
Pengembangan usaha/ pemasaran & 0.107 & 3 & 0.321 \\
Harga jual sapi tinggi & 0.143 & 3 & 0.429 \\
Subtotal & $\mathbf{0 . 6 4 2 9}$ & & $\mathbf{1 . 9 2 9}$ \\
Ancaman & & & \\
Penyakit dari luar daerah & & 2 & 0.214 \\
Keamanan ternak sapi & 0.107 & 2 & 0.214 \\
Perubahan iklim dan cuaca & 0.107 & 2 & 0.143 \\
Adanya pesaing dari luar & 0.071 & 3 & 0.214 \\
Subtotal & 0.071 & $\mathbf{0 . 7 8 6}$ \\
Total & $\mathbf{0 . 3 5 7}$ & $\mathbf{1 . 1 4 3}$ \\
\hline
\end{tabular}

Hasil analisis faktor ekternal yang terdiri atas faktor peluang (opportunity) dan ancaman (threats) menunjukkan bahwa faktor peluang memiliki nilai yang lebih tinggi daripada faktor ancaman dengan nilai selisish sebesar 1.143. Dimana nilai faktor peluang sebesar 1.929 sedangkan nilai faktor

Tabel 4. Matrik SWOT

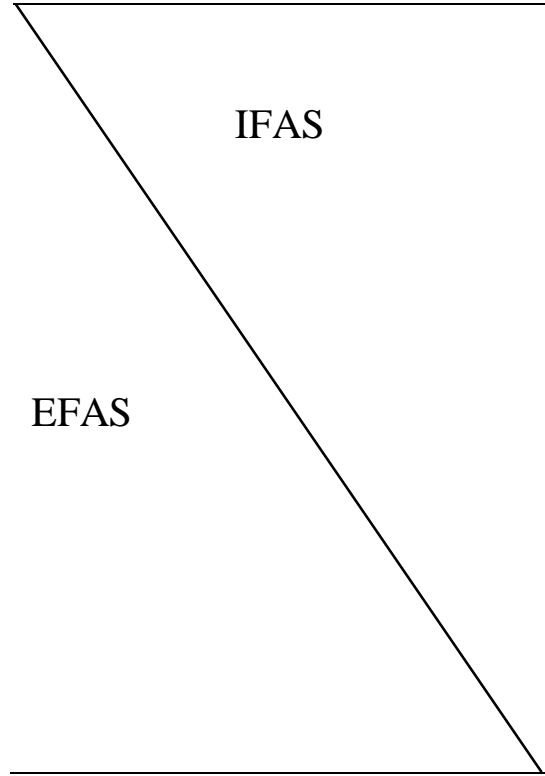

\section{Strenghts:}

1. Populasi ternak sapi tinggi

2. Jumlah SDM peternak tinggi

3. Adanya dukungan pemerintah dan swasta

4. Adanya teknologi reproduksi

5. Adanya kelembagaan peternakan
Weaknesses:

1. Sistem perkandangan yang belum terintegrasi

2. Kualitas SDM peternak rendah

3. Jumlah petugas peternakan masih kurang

4. Kurangnya ketersediaan dan pengelolaan saranaprasarana agribisnis ternak

5. Sistem peternakan yang masih 
tradisional

\section{Opportunities:}

1. Permintaan ternak sapi baik dari dalam maupun luar daerah tinggi

2. Industri pengolahan

3. Adanya Taman Teknologi Pertanian (integrasi sapijagung)

4. Pengembangan usaha/spemasaran

5. Harga jual sapi tinggi

\section{Strategi (SO): stategi pemanfaatan kekuatan untuk meraih peluang}

1. Peningkatan populasi dan produktivitas ternak sapi dengan memanfaatkan teknologi reproduksi, dan taman teknologi pertanian.

2. Meningkatkan

pengetahuan

keterampilan

peternak

pelatihan manajemn usaha dan pemanfaatan teknologi peternakan.

3. Integrasi sistem agribisnis ternak sapi dari hulu ke hilir.

4. Optimalisasi peran dan dukungan pemerintah dan swasta dalam mengembangkan usaha agribisnis ternak sapi.
Threats:

1. Penyakit dari luar daerah

2. Keamanan ternak sapi

3. Perubahan iklim dan cuaca

4. Adanya pesaing dari luar
Strategi (ST): stategi

pemanfaatan kekuatan untuk mengatasi ancaman

1. Peningkatan kuantitas dan kualitas produksi ternak sapi

2. Optimalisasi kelembagaan peternakan

\section{Strategi (WO): stategi meminimalisir kelemahan dengan memanfaatkan} peluang

1. Peningkatan kapasitas peternak melalui pelatihan dan penyuluhan tentang manajemen usaha, pemanfaatan teknologi pengolahan hasil ternak.

2. Peningkatan dan optimalisasi penggunaan sarana dan prasarana pengembangan usaha agribisnis ternak sapi

3. Perbaikan sistem peternakan melalui penerapan sistem agribisnis ternak sapi terintegrasi
Strategi (WT):strategi meminimalisir kelemahan untuk menghindari ancaman

1. Peningkatan jumlah dan peran petugas peternakan dalam melakukan pelatihan dan penyuluhan kesehatan ternak sapi

2. Penggunaan sistem perkandangan terintegrasi untuk menghindari pencurian ternak. 


\section{Strategi Pengembangan Agribisnis Ternak Sapi}

Untuk mengetahui strategi pengembangan agribisnis ternak sapi di Kabupaten Sumbawa Barat maka perlu dibuat matrik space.:

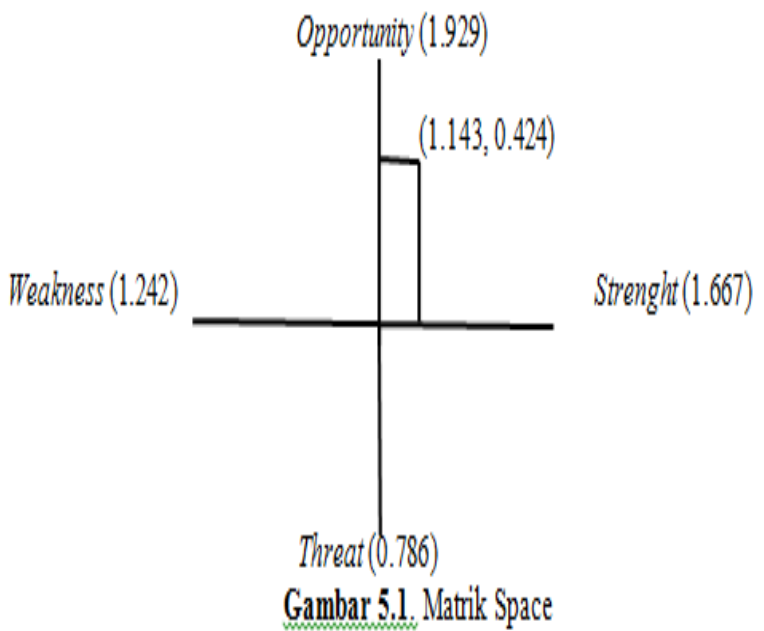

Berdasarkan hasil analisis faktor internal dan dan eksternal maka dapat dirumuskan bahwa strategi pengembangan agribisnis sapi di Kabupaten Sumbawa Barat adalah strategi strength-opportunity (SO). Strategi ini merumuskan bahwa upaya memanfaatkan dan menerapkembangkan kekuatan-kekuatan yang ada untuk dapat mengoptimalkan pemanfaatan peluang yang masih terbuka lebar. Dengan demikian yang termasuk dalam strategi SO untuk strategi pengembangan agribisnis ternak sapi di Kabupaten Sumbawa Barat yaitu sebagai berikut:

1. Peningkatan populasi dan produktivitas ternak sapi dengan memanfaatkan teknologi reproduksi, dan taman teknologi pertanian.

Peningkatan populasi dan produktivitas ternak sapi di Kabupaten Sumbawa Barat dilakukan dengan upaya perbaikan mutu genetik ternak sapi sehingga menghasilkan keturunan yang superior. Beberapa teknologi yang perlu di sosialisasikan dan didesiminasikan kepada para peternak adalah pemanfaatan jasa IB (Inseminasi Buatan) bagi para peternak dengan sistem peternakan intensif dan pengaturan pola perkawinan alam dengan pejantan unggul bagi para peternak dengan sitem ekstensif. Hasil sesuai dengan temuan Yulianti et al., (2021) yang menyatakan bahwa pengembangan peternakan sapi di Provinsi Nusa Tenggara Barat dapat dilakukan dengan memanfaatkan teknologi inseminasi buatan untuk peternakan intensif dan pemilihan ternak pejantan unggul pada peternakan ekstensif. Selain itu adanya taman teknologi maka dapat dijadikan tempat produksi bibit dan bakalan sapi unggul untuk pengembangan agribisnis peternakan.

2. Meningkatkan pengetahuan dan keterampilan SDM peternak melalui pelatihan manajemen usaha dan pemanfaatan teknologi peternakan. Peningkatan pengetahuan dan keterampilan SDM peternak penting dilakukan untuk mendukung pengembangan agribisnis ternak sapi di Kabupaten Sumbawa Barat. Selama ini usaha peternakan sapi masih tradisional dan hanya dijadikan usaha sambilan oleh peternak sehingga belum ada manajemen usaha yang baik (Luanmase et al., 2011). Strategi ini dapat dilakukan melalui pelatihan yang bekerjasama dengan taman teknologi pertanian sebagai tempat pelatihan bisnis, pembuatan pakan dan pengolahan hasil ternak dan lain sebagainya. Hasil ini sesuai dengan temuan Khusna et al., (2016) dan 
Suyudi et al., (2016) yang menyatakan bahwa strategi yang dapat diterapkan dalam rangka pengembangan usaha ternak sapi yaitu melalui peningkatan pengetahuan dan keterampilan peternak dengan melakukan kerjasama dengan lembaga pelatihan terkait manajemen dan pemanfaatan teknologi tepat guna untuk meningkatkan efisiensi usaha.

3. Integrasi sistem agribisnis ternak sapi dari hulu ke hilir.

Pengembangan agribisnis sapi dapat dilakukan dengan menerapkan sistem agribisnis sapi yang terintegrasi dengan tanaman jagung dimana Kabupaten Sumbawa Barat juga sebagai wilayah penghasil jagung. Menurut Abidin et al., (2015) dan Khusna et al., (2016) menyatakan bahwa integrasi agribisnis sapi dengan tanaman pertanian perlu dilakukan dalam rangka pengembangan agribisnis sapi pada subsisitem hulu atau on farm. Pada subsistem subsistem hilir agribisnis sapi dapat dilakukan dengan perbaikan sistem pemasaran melalui berbagai kebijakan (Sumitra et al., 2013). Perbaikan subsistem pengolahan untuk meningkatkan nilai tambah ternak sapi. Dimana menurut Nursan \& Utama (2019) yang menyatakan bahwa pengolahan komoditas pertanian termasuk didalamnya komoditas peternakan penting dilakukan untuk menciptakan nilai tambah produk. Kemudian untuk perbaikan dan pengembangan subsistem hilir penunjang dapat dilakukan dengan memanfaatkan sarana pendukung lainnya seperti rumah portong hewan, pasar ternak dalam rangka pengembangan agribisnis sapi di Kabupaten Sumbawa Barat. Menurut penelitian Khusna et al., (2016), perbaikan dan peningkatan pelayanan sarana penunjang seperti rumah potong hewan dapat meningkatkan produksi daging sapi yang berkualitas

4. Optimalisasi peran dan dukungan pemerintah dan swasta dalam mengembangkan usaha agribisnis ternak sapi.

Peran dan dukungan pemerintah dan swasta terhadap pengembangan agribisnis sapi di Kabupaten Sumbawa Barat perlu dioptimalkan. Peran dan dukungan tersebut yang berupa bantuan bibit dan bakalan sapi maupun permodalan sangat membantu peternak terutama dalam hal mendapatkan faktor produksi dan penggunaan teknologi peternakan sehingga dapat meningkatkan produksi dan produktivitas usaha. Hal ini sesuai dengan pendapat Hermawan \& Andrianyta (2012), bahwa modal sangat penting bagi para pelaku usaha pertanian termasuk peternakan karena selain sebagai faktor produksi juga dapat digunakan untuk meningkatkan kapasitas dan mengadopsi teknologi.

\section{KESIMPULAN DAN SARAN}

Berdasarkan hasil analisis dapat disimpulkan bahwa wilayah basis pengembangan agribisnis ternak sapi di Kabupaten Sumbawa Barat dapat dilakukan di 6 kecamatan yang meliputi Kecamatan Sekongkang, Maluk, Jereweh, Seteluk dan Poto Tano. Strategi pengembangan agribisnis yang perlu diterapkan yaitu strategi strength-opportunity (SO) yang meliputi strategi Peningkatan populasi dan produktivitas ternak sapi dengan memanfaatkan teknologi reproduksi, dan taman teknologi pertanian, meningkatkan 
pengetahuan dan keterampilan SDM peternak melalui pelatihan manajemn usaha dan pemanfaatan teknologi peternakan, integrasi sistem agribisnis ternak sapi dari hulu ke hilir, optimalisasi peran dan dukungan pemerintah dan swasta dalam mengembangkan usaha agribisnis ternak sapi.

\section{DAFTAR PUSTAKA}

Abidin, Z., Siregar, A., Khurniyah, H., \& Yahya, A. (2015). The Analysis of Seasonal Crops Integration of IncomeBeef Cattle Live Stock in Bone Country Bolango Gorontalo Province Indonesia. International Journal of Current Research and Academic Review, 3(6), 148-159.

Arelovich, H., Bravo, R., \& Martínez, M. (2011). Development, Characteristics, and Trends for Beef Cattle Production in Argentina. The Review Magazine of Animal Agriculture, 1(2), 37-45.

Ariani, Z., \& Nursan, M. (2017). Strategi Pengembangan Desa Mantar Sebagai Kawasan Desa Wisata di Kabupaten Sumbawa Barat. Biologi Tropis, 17(2), $58-68$.

BPS KSB. (2021). Kabupaten Sumbawa Barat Dalam Angka Tahun 2021. Badan Pusat Statistik Kabupaten Sumbawa Barat.

Ditjen PKH. (2011). Rencana Strategis Direktorat Jenderal Peternakan dan Kesehatan Hewan 2010-2014 (Edisi Revi). Direktorat Jenderal Peternakan dan Kesehatan Hewan Kementerian Pertanian.

Hermawan, H., \& Andrianyta, H. (2012). Lembaga Keuangan Mikro Agribisnis: Terobosan Penguatan Kelembagaan dan Pembiayaan Pertanian di Perdesaan. Analisis Kebijakan
Pertanian, 10(2), 143-158. https://doi.org/10.21082/akp.v10n2.201 2.143-158

Hilmiati, N. (2019). Sistem Peternakan Sapi Di Pulau Sumbawa: Peluang Dan Hambatan Untuk Peningkatan Produktivitas Dan Pendapatan Petani Di Lahan Kering. SOCA: Jurnal Sosial Ekonomi Pertanian, 13(2), 142-154. https://doi.org/10.24843/soca.2019.v13. i02.p01

Huyen, L., Tuyet, D., Markemann, A., Herold, P., \& Zárate, A. (2012). Beef Cattle Keeping By Smallholders in A Mountainous Province Of Northern Vietnam In Relation To Poverty Status, Community Remoteness And Ethnicity. Journal Animal Production Science, 53(2), 163-172.

Khusna, A., Daryanto, H. K., \& Utami, M. M. D. (2016). Pengembangan Strategi Agribisnis Sapi Potong di Kabupaten Bondowoso. Jurnal Ilmu Pertanian Indonesia, 21(2), 69-75. https://doi.org/10.18343/jipi.21.2.69

Kurniawan, K. (2016). Analisis Sektor Ekonomi Unggulan Kabupaten Kerinci Provinsi Jambi. El-JIZYA Jurnal Ekonomi Islam (Islamic Economics Journal), 41(1), 1-26.

Luanmase, C. M., Nurtini, S., \& Haryadi, F. T. (2011). Analisis Motivasi Beternak Sapi Potong Bagi Peternak Lokal Dan Transmigran Serta Pengaruhnya Terhadap Pendapatan di Kecamatan Kairatu, Kabupaten Seram Bagian Barat. Buletin Peternakan, 35(2), 113123.

Mayulu, H., Sunarso, Sutrisno, C. I., \& Sumarsono. (2010). Kebijakan Pengembangan Peternakan Sapi Potong di Indonesia. Jurnal Penelitian Dan Pengembangan Pertanian, 29(1), 3441. 
https://doi.org/10.21082/jp3.v29n1.201 $0 . \mathrm{p} \% \mathrm{p}$

Mukson, W., Roessali, \& H, S. (2014). Analisis Wilayah Pengembangan Sapi Potong dalam Mendukung Swasembada Daging di Jawa Tengah. Jurnal Peternakan Indonesia, 16(1), 26-32.

http://jpi.faterna.unand.ac.id/index.php/ jpi/article/view/30

Nursan, M. (2017). Penentuan Komoditas Unggulan Tanaman Pangan di Kabupaten Sumbawa Barat. Jurnal Bisnis Tani, 3(1), 78-83.

Nursan, M., \& Septiadi, D. (2020). Penentuan Prioritas Komoditas Unggulan Peternakan di Kabupaten Sumbawa Barat. Jurnal Agribisnis Dan Ilmu Sosial Ekonomi Pertanian, 5(1), 29-34.

Nursan, M., \& Utama, F. A. (2019). Strategi Pengembangan Badan Usaha Milik Desa (Bumdes) Berbasis Pertanian Di Kabupaten Sumbawa Barat. 8(2), 6778.

https://doi.org/http://dx.doi.org/10.2641 8/j.sea.v8i2.37726

Otoluwa, M. A., Salendu, A. H. ., Rintjap, A. K., \& Massie, M. T. (2016). Prospek Pengembangan Usaha Ternak Sapi Potong di Kecamatan Bolangitang Timur Kabupaten Bolaang Mongondow Utara. Jurnal Zootek (“Zootek" Journal ), 36(1), 191-197. https://doi.org/10.35792/zot.36.1.2016. 10469

Priyanto, D. (2011). Strategi Pengembangan USaha Ternak Sapi Potong dalam Mendukung Program Swasembada Daging Sapi dan Kerbau Tahun 2014. Jurnal Penelitian Dan Pengembangan Pertanian, 30(3), 108-116. https://doi.org/10.21082/jp3.v30n3.201 1.p108-116
Putritamara, J. A., Febrianto, N., \& Ndaru, P. H. (2018). Strategi pemasaran sapi potong di PT Tunas Jaya Raya Abadi Nganjuk. Jurnal Ilmu-Ilmu Peternakan, $28(2)$, 96-104. https://doi.org/10.21776/ub.jiip.2018.0 28.02.01

Rangkuti, F. (2015). Analisis SWOT. PT Gramedia Pustaka Utama.

Rustiadi, E., Saefulhakim, S., \& Panuju, D. R. (2011). Perencanaan dan pembangunan wilayah. Yayasan Pustaka Obor Indonesia.

Siregar, G. (2012). Analisis Kelayakan dan Strategi Pengembangan Usaha Ternak Sapi Potong. Agrium, 17(3), 192-201.

Sugiyono. (2014). Metode Penelitian Kuantitatif Kualitatif dan $R \& D$. Alfabeta.

Sumitra, J., Tri Anggraeni, K., \& Widiati, R. (2013). Pemasaran Ternak Sapi Potong. Buletin Peternakan, 37(1), 49-58.

Suryana. (2009). Pengembangan Usaha Ternak Sapi Potong Berorientasi Agribisnis Dengan Pola Kemitraan. Jurnal Penelitian Dan Pengembangan Pertanian, 28(1), 29-37. https://doi.org/10.21082/jp3.v28n1.200 9.p29

Susanti, Y., Priyarsono, D. S., \& Mulatsih, S. (2014). Pengembangan Peternakan Sapi Potong Untuk Peningkatan Perekonomian Provinsi Jawa Tengah: Suatu Pendekatan Perencanaan Wilayah. Jurnal Agribisnis Indonesia, 2(2), 177-190.

Suyudi, Nuryaman, H., \& Erfan. (2016). Strategi dan Model Pengembangan Usaha Peternakan Sapi Rancah. Jurnal Riset Agribisnis \& Peternakan, 1(2), 25-36.

http://ejournal.umpwr.ac.id/index.php/j rap/article/view/4281 
Tarigan, R. (2014). Ekonomi Regional:

Teori dan Aplikasi. Bumi Aksara.

Yulianti, Humaidah, N., \& Suryanto, D. (2021). Model Pengembangan Peternakan di Nusa Tenggara Barat Terhadap Produktivitas Sapi Bali (Article Review). JURNAL DINAMIKA REKASATWA, 4(1), 83-92. 